\title{
Forum
}

\section{Walking with lions: why there is no role for captive-origin lions Panthera leo in species restoration}

\author{
Luke T.B. Hunter, Paula White, Philipp Henschel, Laurence Frank \\ Cole Burton, Andrew Loveridge, Guy Balme, Christine Breitenmoser and \\ URS BREITENMOSER
}

\begin{abstract}
Despite formidable challenges and few successes in reintroducing large cats from captivity to the wild, the release of captives has widespread support from the general public and local governments, and continues to occur ad hoc. Commercial so-called lion Panthera leo encounter operations in Africa exemplify the issue, in which the captive breeding of the lion is linked to claims of reintroduction and broader conservation outcomes. In this article we assess the capacity of such programmes to contribute to in situ lion conservation. By highlighting the availability of wild founders, the unsuitability of captive lions for release and the evidence-based success of wild-wild lion translocations, we show that captive-origin lions have no role in species restoration. We also argue that approaches to reintroduction exemplified by the lion encounter industry do not address the reasons for the decline of lions in situ, nor do they represent a model that can be widely applied to restoration of threatened felids elsewhere.
\end{abstract}

Keywords Africa, captive breeding, Felidae, lion, Panthera leo, reintroduction, restoration, translocation

\section{Introduction}

aptive breeding and reintroduction of threatened species are often publicized as a solution for the loss of biodiversity. While these are essential tools for the restoration of many taxa (e.g. Stanley Price \& Fa, 2007;

Luke T.B. Hunter (Corresponding author), Philipp Henschel, LaurenCe Frank and GuY Balme Panthera, 8 West 40th Street, 18th Floor, New York, NY 10018, USA. E-mail lhunter@panthera.org

PAUla White Center for Tropical Research, University of California, Los Angeles, USA

Cole BurTon Alberta Biodiversity Monitoring Institute, University of Alberta, Edmonton, Canada

ANDREW LOVERIDGe Wildlife Conservation Research Unit, Zoology Department, Oxford University, UK

Christine Breitenmoser and URS BreItenmoser Co-Chairs, IUCN/SSC Cat Specialist Group, c/o KORA, Muri, Switzerland

Received 14 December 2011. Revision requested 11 May 2012

Accepted 18 May 2012. First published online 31 July 2012
Fa et al., 2011) they are also invoked for species for which there is no record of success. This is true for large felids for which, intentionally or otherwise, popular media and captive collections foster the view that captive big cats will eventually return to the wild (Stanley Price \& Fa, 2007; Guo, 2009). This is compounded by the extraordinary publicity surrounding ad hoc reintroductions such as those of lions Panthera leo undertaken by George and Joy Adamson in the 1950s-1970s.

In reality reintroducing large carnivores from captivity into the wild is profoundly limited by biological, technical, financial and sociological factors. Those factors have been comprehensively reviewed (Beck et al., 1994; Breitenmoser et al., 2001; Jule et al., 2008; Clark, 2009) yet there remains a troubling trend for ad hoc reintroduction efforts using captive individuals. Elsewhere, we have discussed failed reintroduction attempts for captive Eurasian lynx Lynx lynx (Breitenmoser \& Breitenmoser-Würsten, 2008) and jaguars Panthera onca (Hunter \& Rabinowitz, 2009), and there are controversial projects proposing the release of zoo-born tigers Panthera tigris and leopards Panthera pardus (Khosravifard, 2010; Rozhnov et al., 2011). In this article we examine commercial lion encounter programmes in Africa that promote captive breeding of lions as a putative source for reintroduction. This process typically involves close contact with hand-raised cubs removed at a young age from the mother (e.g. ALERT, 2011a), providing a source of tame lions with which tourists and volunteers can interact for a fee (e.g. USD 195 per half-day to USD 3,573 for 28 days; Lion Encounter, 2011). The stated objective of these programmes is to release the offspring of hand-raised lions, which will be permitted to grow up without human interference (Guo, 2009), although, as of this writing, this has not taken place.

We do not cover identifying and preparing the release site, an essential first step for reintroducing any large carnivore (Breitenmoser et al., 2001). Assuming that suitable reintroduction sites exist, we focus on whether founder animals should come from wild vs captive origins. Specifically, we assess the need for and suitability of captive lions and their offspring in restoration efforts for the species in Africa. We also assess the value of 
the lion encounter industry as a potential model for using captive large cats as candidates for reintroduction elsewhere.

\section{Is there a need for captive-origin lions in reintroduction?}

Since 1991 well-monitored efforts to restore lions to areas of the species' former range have been underway in South Africa and Namibia. All of these efforts involved the capture and translocation of wild lions (for a detailed description of methods see Hunter et al., 2007). By 2007 at least 37 reserves totalling $6,467 \mathrm{~km}^{2}$ had re-established lions using wild founders (Slotow \& Hunter, 2009). The resulting lion population numbered $>450$ in 2007 and since then wild lions have been reintroduced into four additional sites, in Mozambique, Namibia, Zambia and Zimbabwe (Lindsey \& Bento, 2010; L. T. B. Hunter, unpubl. data). While the scientific rigour of post-release management varies depending on the capacity of site managers (see Slotow \& Hunter, 2009, for a critique), population reestablishment using wild lions has been unequivocally successful. With 20 years of monitoring data informing the process, translocating wild lions to both establish new populations and supplement declining populations (Trinkel et al., 2008) has become routine.

That said, translocation relies on suitable wild source populations. Claims that 'only six geographically clustered [wild] populations contain sufficient individuals to potentially serve as a source for reintroduction,' (ALERT, 2011a: 17) are specious. Lion populations recover rapidly from drastic declines (Smuts, 1978; Munson et al., 2008) and even small populations withstand controlled removal without longterm numerical consequences (Slotow \& Hunter, 2009). As repeatedly demonstrated by the South African restorations, successful reintroduction requires conservative removals from the source, typically one or two prides (or equivalent numbers of individual lions or partial prides) at one time (Van Dyk, 1997). This is easily sustained by even small wild lion populations and represents a compensatory, rather than additive, removal in a well-planned translocation. The original founders for the South African projects came from one large population (the Greater Kruger ecosystem) and two smaller populations (Etosha National Park and Kgalagadi Transfrontier Park) that have remained stable or increased (IUCN, 2006; Ferreira \& Funston, 2010). Furthermore, secondary populations were subsequently created by translocating lions from much smaller, newly restored populations as they increased. Despite population control measures that included translocation, contraception and culling, 12 reintroduced lion populations established between 1992 and 1999 (i.e. those with sufficient data at the time of analysis) had a rate of increase of 1.18-1.71 (Vartan, 2002; Slotow \& Hunter, 2009).
Removals for translocation would be problematic if they compromised the source population; for example, by increasing the likelihood of inbreeding. The risk potentially increases as population size decreases (Björklund, 2003) but, as for demographic parameters, risk can be mitigated by careful selection of founders; for example, by selecting dispersers or prides near the boundaries of protected populations, which suffer high rates of lethal control and low recruitment success (Van Dyk, 1997; Hunter et al., 2007). Additionally, lion populations are highly panmictic (Dubach et al., 2005; Antunes et al., 2008) and marked inbreeding depression is known only in two isolated populations arising from extremely few founders: in the Ngorongoro Crater, Tanzania (Packer et al., 1991) and Hluhluwe-iMfolozi, South Africa (Trinkel et al., 2008). Such small, inbred populations would be a poor source, as would other small and isolated lion populations for which removing individuals could increase the likelihood of inbreeding among remaining animals. However, there is simply no reason to draw on small and/or inbred populations when other, more suitable candidate sources exist.

Disease in the source population is also a potential concern, given that the translocation of lions may also transport pathogens. Wild lions are host to a variety of viral, bacterial and parasitic pathogens but disease is rare in wild populations (Packer et al, 1999). The catastrophic 1994 and 2001 canine distemper virus (CDV) outbreaks in Tanzania arose from a perfect storm of climatic extremes prompting elevated Babesia coinfections that led to unprecedented mortality (Munson et al., 2008). CDV generally lacks clinical signs or measurable mortality in lions, and previous CDV events in that population were relatively innocuous (Packer et al., 1999). Other pathogens such as feline herpes virus, feline calicivirus, feline parvovirus and coronavirus are widespread in lions but rarely cause illness (Spencer 1992; Packer et al., 1999; Trinkel et al., 2011).

Two pathogens, feline immunodeficiency virus (FIV) and bovine tuberculosis, are particularly relevant to the translocation debate. FIV causes an AIDS-like syndrome in domestic cats but it appears to be co-adapted in eight free-ranging species of Felidae, including lions, which are endemic with largely non-pathogenic FIV strains. Low-grade pathologies are associated with FIV infection in wild Botswanan lions but elevated morbidity or mortality is not observed (Roelke et al., 2009). Similarly, although every Serengeti and Ngorongoro lion is FIV-positive by 4 years of age they do not suffer higher age-specific mortality than uninfected populations, and lions infected at early ages do not have shorter life spans than lions infected at older ages (Packer et al., 1999; Troyer et al., 2004).

During the 1994 Serengeti CDV outbreak, certain FIV clades were implicated in elevating susceptibility to co-infection with CDV but the effect was only marginally 
statistically significant (O’Brien et al., 2012). FIV-positive Hluhluwe-iMfolozi lions were apparently unaffected despite recent exposure to the virus and significant inbreeding depression that could be expected to elevate vulnerability (Trinkel et al., 2011). Despite the lack of disease the presence of FIV is employed as an argument for preferring captive, FIV-negative animals (Guo, 2009). Even if FIV is ultimately shown to affect lion populations, FIV-negative wild lions such as those in Etosha National Park are available (also circumventing the considerable problems associated with reintroducing captive lions; see next section).

Finally, lions are vulnerable to bovine tuberculosis (bTB) caused by Mycobacterium bovis bacterial infection. bTB is an exotic livestock disease now present in much of Africa in which transmission to lions is via infected wild ungulates (Ferreira \& Funston, 2010). The disease is poorly understood in lions but is believed to contribute to poor health in extreme cases. Thirty percent of the severely inbred Hluhluwe-iMfolozi lion population died from bTB (combined with malnutrition) in 2000-2009, although $<2 \%$ of outbred lions translocated into this population were affected in the same period (Trinkel et al., 2011). Similarly, the effect was considered negligible in the outbred population in Kruger (Ferreira \& Funston, 2010). The presence of bTB in lions in southern Africa has prevented translocations, primarily because of veterinary restrictions intended to protect domestic livestock.

The widespread prevalence and limited health effects of most known lion pathogens suggests the risk of introducing novel diseases from wild founders to the release site is relatively low, especially if founders come from nearby populations (see next section). We do not believe this should promote complacency towards the possible movement of pathogens, and any translocation programme must include screening for diseases. However, there is currently no evidence suggesting that wild founders are more likely than captives to be a source of novel disease in newly established populations. Indeed, wild animals are potentially less likely reservoirs than captives, which may be exposed to a greater range of exotic pathogens (see next section). In summary, there is a large body of evidence showing that wild lion populations continue to be viable sources for reintroduction exercises and we can find no reason to resort to using captive-origin lions.

\section{What is the suitability of captive-origin lions for reintroduction?}

Assuming a demonstrable need for captive-origin lions arises in future, would they be suitable for reintroduction? Restoration efforts across a wide variety of taxa using wild-caught individuals are typically more successful than those using captive animals ( $75 \%$ vs $38 \%$, Griffith et al., $1989 ; 71 \%$ vs $49 \%$, Wolf et al., $1996 ; 31 \%$ vs $13 \%$, Fischer
\& Lindenmayer, 2000). This is particularly true for large carnivores, especially those with complex social dynamics such as lions, in which captives are poorly equipped for survival compared to their wild counterparts (Breitenmoser et al., 2001; Jule et al., 2008; Clark, 2009). Furthermore, the impoverished setting of the captive environment may lead to maladaptive behaviour. Aberrant behaviours documented among captive prides intended for release have included males inexplicably killing adult females, necessitating removal of the males, and high cub mortality as a result of 'failing to thrive' and being kidnapped and killed by a pride female (ALERT, 2011b). Such maladaptive behaviours are unknown among cohesive social groups of wild founders in the South African translocation projects and would represent a significant setback in a genuine restoration effort.

The second, most significant problem with captive lions is one of origin. Ideally, founders should be genetically similar to the historical residents of the release site (Frankham, 2009). As specified by the IUCN Re-introduction Specialist Group 'It is desirable that source animals come from wild populations. If there is a choice of wild populations to supply founder stock for translocation, the source population should ideally be closely related genetically to the original native stock and show similar ecological characteristics (morphology, physiology, behaviour, habitat preference) to the original sub-population' (IUCN, 1998). Captive-bred lions may lack important local adaptations and, in the case of hand-raised animals, are selected for their tolerance of close contact with humans rather than by any natural selective process. Additionally, introduction of novel pathogens by captive animals could be catastrophic to wild populations (Daszak et al., 2000). Captive-bred carnivores are exposed to an unnatural variety of pathogens from close contact with other captive species and humans (Williams \& Thorne, 1996, Martella et al., 2007) yet they can only be screened for a limited number of wellknown diseases (and screening may fail; Trinkel et al., 2011).

Accordingly, we agree with the IUCN (1998) recommendation that founders should come from similar or nearby wild populations where origin is unequivocal. In southern Africa a long history of private ownership of lions from various sources (e.g. ALERT, 2011b) has created a mongrel captive population that is not managed under accredited breeding programmes, which maintain lineages according to geographic and genetic provenance (Pfaff, 2003, 2010). Based on their uncertain or hybrid origins alone, these lions should never be considered for release in or near established wild populations. This is especially germane in West and Central Africa, where the need for reintroduction is arguably greatest (Henschel et al., 2010; Burton et al., 2011). However, West and Central African lions are genetically distinct (Bertola et al., 2011) and are poorly represented in captivity (Pfaff, 2003, 2010), further 
precluding the applicability of the lion encounter model there (Anonymous, 2010). Instead, the tri-national W-ArliPendjari Complex, with c. 500 lions (Sogbohossou, 2011), and the Bénoué Complex in Cameroon, with c. 200 lions (Croes et al., 2011), represent a viable source for potential wild-wild translocations in West and Central Africa, respectively, should opportunities for restoration arise.

Finally, even assuming some unforeseen need for captive-origin lions in reintroductions arises in future, we see no acceptable role for so-called pre-release training (ALERT, 2008, Lion Encounter, 2011) that demands close contact between people and tame lions. Any credible attempt to reintroduce captive cats includes stringent safeguards against socializing animals to humans. In contrast, the lion encounter industry relies on animals so habituated to human presence that they can never be released. It is questionable whether even offspring of human-socialized lions would be suitable for release but, regardless, the step involving close contact with people is unnecessary at best and dangerous at worst. Untrained volunteers are placed in extraordinarily dangerous situations that have resulted in attacks, including fatalities (Raferty, 2011). Similarly, recent releases in India of captive leopards and tigers have ended disastrously, with both human and cat fatalities (Dattatri, 2011).

\section{Conclusion}

We find little of conservation value that justifies the use of captive-origin lions for reintroduction. The widespread availability of wild founders, in concert with the formidable challenges of reintroducing captive lions, repudiates any need for resorting to captives. The only restoration scenario we can envision in which captive animals could be useful is for regions where the lion is long extinct and captive collections hold the closest genetic match. This may apply for the so-called Barbary lion, which was extirpated from North Africa by the 1940s. However, it is extremely unlikely that pure North African founders exist, the captive population is small and inbred, and the challenges of overcoming $>100$ years of captive existence would be significant (Barnett et al., 2006; Black et al., 2010).

In conclusion, even under the best possible circumstances, breeding lions in captivity does little to address the root causes of the species' decline in the wild. Resources and attention would be more productively steered towards securing existing lion habitat and mitigating anthropogenic killing of lions and their prey. This would help stem the rapid decline of the wild lion as well as enhance existing populations for further reintroduction opportunities as they arise (Hunter et al., 2007). Current proposals for reintroduction of captive lions contribute little to these issues and instead distract from meaningful efforts to conserve the lion in situ. Finally, given that no lions have been restored to the wild by this process since efforts started in 1999 (ALERT, 2008), a period during which hundreds of wild founders have been translocated successfully, it cannot be considered a model that should be widely adopted for large felids. For the greatest chance of success we recommend any future proposals to reintroduce mediumlarge felids with captive founders are modelled on the only two credible examples currently underway: the Iberian Lynx Conservation Programme (Vargas et al., 2008) and a strategy to establish a second in situ population of the Amur leopard (Christie, 2009). Both are characterized by meticulous planning and rigorous peer-review at every stage.

\section{Acknowledgements}

We are grateful to Howard Quigley, Tom McCarthy, Craig Packer and three anonymous reviewers for critical comments.

\section{References}

ALERT (2008) Annual Report 2008. Unpublished Report. African Lion and Environmental Research Trust, Livingstone, Zambia.

ALERT (2011a) Find Your Pride. Unpublished Report. African Lion and Environmental Research Trust, Livingstone, Zambia.

ALERT (2011b) Lions in the Program. Http://www.lionalert.org/pages/ lionsintheprogram.html [accessed 1 December 2011].

Anonymous (2010) Lions Reserve on Shai Hills to be Established. Http://www.pathghana.com/lions-reserve-on-shai-hills-tobe-established.html [accessed 13 May 2012].

Antunes, A., Troyer, J.L., Roelke, M.E., Pecon-Slattery, J., PaCker, C., Winterbach, C. et al. (2008) The evolutionary dynamics of the lion Panthera leo revealed by host and viral population genomics. PLoS Genetics, 4, e1000251.

Barnett, R., Yamaguchi, N., Barnes, I. \& Cooper, A. (2006) Lost population and preserving genetic diversity in the lion Panthera leo: implications for its ex situ conservation. Conservation Genetics, 7, 507-514.

Beck, B.B., Rapaport, L.G., Stanley Price, M.R. \& Willon, A.C. (1994) Reintroduction of captive-born animals. In Creative Conservation: Interactive Management of Wild and Captive Animals. (eds P.J.S. Olney, G.M. Mace \& A.T.C. Feistner), pp. 264-386. Chapman \& Hall, London, UK.

Bertola, L.D., van Hooft, W.F., VRieling, K., Uit de Weerd, D.R., York, D.S., B AUeR, H., et al. (2011) Genetic diversity, evolutionary history and implications for conservation of the lion (Panthera leo) in West and Central Africa. Journal of Biogeography, $38,1356-1367$.

BJÖRKLUND, M. (2003) The risk of inbreeding due to habitat loss in the lion (Panthera leo). Conservation Genetics, 4, 515-523.

Black, S., Yamaguchi, N., Harland, A. \& Groombridge, J. (2010) Maintaining the genetic health of putative Barbary lions in captivity: an analysis of Moroccan Royal Lions. European Journal of Wildlife Research, 56, 21-31.

Breitenmoser, U. \& Breitenmoser-Würsten, C. (2008) Der Luchs -ein Grossraubtier in der Kulturlandschaft. Salm Verlag, Wohlen/ Bern, Switzerland. 
Breitenmoser, U., Breitenmoser-Wursten, C., Carbyn, L.N. \& FUNK, S.M. (2001) Assessment of carnivore reintroductions. In Carnivore Conservation (eds J.L. Gittleman, S.M. Funk, D. Macdonald \& R.K. Wayne), pp. 241-281. Cambridge University Press, Cambridge, UK.

Burton, A.C., Buedi, E.B., Balangtaa, C., Kpelle, D.G., Sam, M.K. \& Brashares, J.S. (2011) The decline of lions in Ghana's Mole National Park. African Journal of Ecology, 49, 122-126.

Christie, S. (2009) Breeding Far Eastern leopards for reintroduction: the zoo programme perspective. In Iberian Lynx ex situ Conservation: An Interdisciplinary Approach (eds A. Vargas, C. Breitenmoser \& U. Breitenmoser), pp. 462-478. Fundación Biodiversidad, Madrid, Spain.

CLARK, J.D. (2009) Aspects and implications of bear reintroduction. In Reintroduction of Top-Order Predators (eds M.W. Hayward \& M. Somers), pp. 126-145. Blackwell Publishing, Oxford, UK.

Croes, B.M., Funston, P.J., Rasmussen, G., Buij, R., Saleh, A. \& Tumenta, P.N. (2011) The impact of trophy hunting on lions (Panthera leo) and other large carnivores in the Bénoué Complex, northern Cameroon. Biological Conservation, 144, 3064-3072.

Daszak, P., Cunningham, A.A. \& Hyatt, A.D. (2000) Emerging infectious diseases of wildlife: threats to biodiversity and human health. Science, 287, 443-449.

Dattatri, S. (2011) Killer Cats. The Dangers of Captive Carnivore Introductions. Unpublished Report. Conservation India, Bangalore, India.

Dubach, J., Patterson, B.D., Briggs, M.B., Venzke, K., Flamand, J., Stander, P. et al. (2005) Molecular genetic variation across the southern and eastern geographic ranges of the African lion, Panthera leo. Conservation Genetics, 6, 15-24.

FA, J.E., Funk, S.M. \& O'Connell, D.M. (2011) Zoo Conservation Biology. Cambridge University Press, Cambridge, UK.

Ferreira, S.M. \& Funston, P.J. (2010) Estimating lion population variables: prey and disease effects in Kruger National Park, South Africa. Wildlife Research, 37, 194-206.

Fischer, J. \& Lindenmayer, D.B. (2000) An assessment of the published results of animal relocations. Biological Conservation, 96, 1-11.

Frankham, R. (2009) Genetic considerations in reintroduction programmes for top-order terrestrial predators. In Reintroduction of Top-Order Predators (eds M.W. Hayward \& M. Somers), pp. 371-387. Blackwell Publishing, Oxford, UK.

Griffith, B., Scott, J.M., Carpenter, J.W. \& Reed, C. (1989) Translocations as a species conservation tool: status and strategy. Science, 245, 477-480.

Guo, J. (2009) Will captive breeding save Africa's King of Beasts? Science, 324, 331.

Henschel, P., Azani, D., Burton, C., Malanda, G., Saidu, Y., SAM, M. \& Hunter, L.T.B. (2010) Lion status updates from five range countries in West and Central Africa. Cat News, 52, 34-39.

Hunter, L.T.B., Pretorius, K., Carlisle, L., Rickelton, M., Walker, C., Slotow, R. \& Skinner, J.D. (2007) Restoring lions Panthera leo to Northern KwaZulu-Natal, South Africa: short-term biological and technical success but equivocal long-term conservation. Oryx, 41, 196-204.

Hunter, L.T.B. \& Rabinowitz, A. (2009) Felid reintroduction using captive founders: poor science and worst practices. Cat News, $51,32-33$.

IUCN (1998) Guidelines for Re-introductions. IUCN/Species Survival Commission Re-introduction Specialist Group. IUCN, Gland, Switzerland and Cambridge, UK.

IUCN (2006) Conservation Strategy for the Lion (Panthera leo) in Eastern and Southern Africa. IUCN/Species Survival Commission Cat Specialist Group, Gland, Switzerland and Cambridge, UK.
Jule, K.R., Leaver, L.A. \& Lea, S.E.G. (2008) The effects of captive experience on reintroduction survival in carnivores: a review and analysis. Biological Conservation, 141, 355-363.

Khosravifard, S. (2010) Russia, Iran exchange tigers for leopards but some experts express doubts. Http://www.payvand.com/news/10/ may/1232.html [accessed 13 May 2012].

Lindsey, P. \& Bento, C. (2010) Illegal Hunting and the Bushmeat Trade in Central Mozambique: A Case-study from Coutada 9, Manica Province. TRAFFIC, Harare, Zimbabwe.

Lion Encounter (2011) Rehabilitation \& Release into the Wild Program, Zimbabwe \& Zambia 2011. Lion Encounter, Livingstone, Zambia.

Martella, V., Campolo, M., Lorusso, E., Cavicchio, P., Camero, M., Bellacicco, A.L. et al. (2007) Norovirus in a captive lion cub (Panthera leo). Emerging Infectious Diseases, 13, 1071-1073.

Munson, L., Terio, K.A., Kock, R., Mlengeya, T., Roelke, M.E., Dubovi, E. et al. (2008) Climate extremes promote fatal coinfections during canine distemper epidemics in African lions. PLoS ONE, 3, e2545.

O’Brien, S.J., Troyer, J.L., Brown, M.A., Johnson, W.E., Antunes, A., Roelke, M.E. \& Pecon-Slattery, J. (2012) Emerging viruses in the Felidae: shifting paradigms. Viruses, 4, 236-257.

Packer, C., Altizer, S., Appel, M., Brown, E., Martenson, J., O'Brien, S.J. et al. (1999) Viruses of the Serengeti: patterns of infection and mortality in African lions. Journal of Animal Ecology, $68,1161-1178$

Packer, C., Pusey, A.E., Rowley, H., Gilbert, D.A., Martenson, J. \& O'BRIEN, S.J. (1991) Case study of a population bottleneck: lions of the Ngorongoro crater. Conservation Biology, 5, 219-230.

Pfaff, S.E. (2003) African Lion Studbook. Riverbanks Zoological Park, Columbia, USA.

Pfaff, S.E. (2010) North American Regional African Lion Studbook. Riverbanks Zoological Park, Columbia, USA.

RAFERTY, M. (2011) A walk on the wild side proves perilous for east county woman attacked by lion in Africa. East County Magazine. Http://www.eastcountymagazine.org/node/6120 [accessed 13 May 2012].

Roelke, M.R., Brown, M.A., Troyer, J.L., Winterbach, H., Winterbach, C., Hemson, G. et al. (2009) Pathological manifestations of feline immunodeficiency virus (FIV) infection in wild African lions. Virology, 390, 1-12.

Rozhnov, V.V., Lukarevskiy, V.S. \& Sorokin, P.A. (2011) Application of molecular genetic characteristics for reintroduction of the leopard (Panthera pardus L., 1758) in the Caucasus. Doklady Biological Sciences, 437, 97-102.

Slotow, R. \& Hunter, L.T.B. (2009) Reintroduction decisions taken at the incorrect social scale devalue their conservation contribution: the African lion in South Africa. In Reintroduction of Top-Order Predators (eds M. Hayward \& M. Somers), pp. 43-71. Blackwell Publishing, Oxford, UK.

Smuts, G.L. (1978) Effects of population reduction on the travels and reproduction of lions in Kruger National Park. Carnivore, 1, $61-72$.

Sogbohossou, E. (2011) Lions of West Africa: ecology of lion (Panthera leo Linnaeus 1975) populations and human-lion conflicts in Pendjari Biosphere Reserve, North Benin. $\mathrm{PhD}$ thesis, Leiden University, Leiden, Netherlands.

Spencer, J.A. (1992) Survey of antibodies to feline viruses in free-ranging lions. South African Journal of Wildlife Research, 21, $59-61$.

Stanley Price, M. \& FA, J.E. (2007) Reintroductions from zoos: a conservation guiding light or shooting star? In Zoos in the 21st 
Century: Catalysts for Conservation? (eds A. Zimmermann, M. Hatchwell, L.A. Dickie \& C. West), pp. 155-177. Cambridge University Press, Cambridge, UK.

Trinkel, M., Cooper, D., Packer, C. \& Slotow, R. (2011) Inbreeding depression increases susceptibility to bovine tuberculosis in lions: an experimental test using an inbred-outbred contrast through translocation. Journal of Wildlife Diseases, 47, 494-500.

Trinkel, M., Ferguson, N., Reid, A., Reid, C., Somers, M., Turelli, L. et al. (2008) Translocating lions into an inbred lion population in the Hluhluwe-iMfolozi Park, South Africa. Animal Conservation, 11, 138-143.

Troyer, J.L., Pecon-Slattery, J., Roelke, M.E., Black, L., Packer, C. \& O’Brien, S.J. (2004) Patterns of feline immunodeficiency virus multiple infection and genome divergence in a free-ranging population of African lions. Journal of Virology, 78 , $3777-3791$.

VAN DyK, G. (1997) Reintroduction techniques for lion (Panthera leo). In Proceedings of a Symposium on Lions and Leopards as Game Ranch Animals (ed. J. van Heerden), pp. 82-91. University of Pretoria, Pretoria, South Africa.

Vargas, A., Sanchez, I., Martinez, F., Rivas, A., Godoy, J., Roldán, E. et al. (2008) The Iberian lynx Lynx pardinus conservation breeding program. International Zoo Yearbook, 42, 190-198.

VARTAN, S. (2002) Overpopulation and inbreeding in small game reserves: the lion Panthera leo as a case study. MSc thesis, University of Cape Town, Rondebosch, South Africa.

Williams, E.S. \& Thorne, E.T. (1996) Infectious and parasitic diseases of captive carnivores, with special emphasis on the black-footed ferret (Mustela nigripes). Revue Scientifique et Technique Office Internationale des Epizooties, 15, 91-114.

Wolf, C.M., Griffith, B., Reed, C. \& Temple, S.A. (1996) Avian and mammalian translocations: update and reanalysis of 1987 survey data. Conservation Biology, 10, 1142-1154.

\section{Biographical sketches}

Luke Hunter is the President of Panthera and has worked on the conservation of wild African cats since 1992. PAULA WHITE is the Director of the Zambia Lion Project and focuses on developing sustainable trophy hunting practices of the species. PHILIPP HENSCHEL undertook the first comprehensive study of forest leopards in Gabon and now heads Panthera's lion survey efforts, targeting the most imperiled populations. LAURENCE FRANK has studied carnivore ecology, behaviour and conservation for over 40 years. He currently directs the Living with Lions program in Kenya, which focuses on conserving viable carnivore populations in human dominated landscapes. COLE BURTON's research interests include carnivore conservation, human-wildlife conflict and monitoring effectiveness. ANDREW LOVERIDGE has worked on the management, ecology and conservation of wild lions since 1999. Guy Balme is the Director of Panthera's Lion Program in Africa and also heads the organization's efforts to address poorly regulated trophy hunting and legal control of leopards in Africa. Christine and URS BREITENMOSER are the joint chairs of the IUCN/SCC Cat Specialist Group, and have fostered strategic conservation planning initiatives for several cat species in Europe, Africa and Asia. 